\title{
ELIAS HERCKMANS. A POET AT THE BORDERS OF DUTCH BRAZIL
}

\author{
Britt Dams
}

As I am preparing this paper, the French academic world is celebrating the 100th birthday of Claude Lévi-Strauss, who was born in 1908 and lived in Brazil from 1935 until 1939. In the course of four years of ethnographic research there, he stayed among local tribes twice. Back in France, as he was reflecting on his work, Lévi-Strauss realized the experience was not exactly the sort of thing that he had hoped for. Even though he had collected precious information and his work had been praised internationally, he had the impression that the indigenous reality would remain forever inaccessible. While writing Tristes Tropiques, as he puts it, he faced an 'insurmountable circle'. ${ }^{1}$ About 300 years earlier, Elias Herckmans, a national poet, was sent out by the Dutch West India Company to Brazil where he was also confronted with this culturally other reality. The question that is central to my analysis is quite straightforward: How did Herckmans respond to this otherness?

\section{Dutch Brazil}

The Dutch colonists participating in the Brazilian adventure are often portrayed as traders seeking for profit. Neither interested in the founding of a settlement, nor in the local reality, it is generally assumed that they did not try to adjust to their new environment, but rather stuck to their old habits and customs. Almost everything they needed was imported from their home country, from building material over food to prostitutes.

\footnotetext{
1 'Et voici, devant moi, le cercle infranchissable: moins les cultures humaines étaient en mesure de communiquer entre elles et donc de se corrompre par leur contact, moins aussi leurs émissaires respectifs étaient capables de percevoir la richesse et la signification de la diversité.' Lévi-Strauss C., Tristes Tropiques (Paris: 1955) 43.
} 
This is of course a generalisation and the opposite affirmation can be made as well. From 1637 until 1644, Johan-Maurits (1604-1679), Count of Nassau-Siegen, was appointed governor-general of Dutch Brazil. As the highest representative of the WIC, which had been founded in 1621, he ruled the colony located in the northeast of present-day Brazil. Johan-Maurits is well known for his collections of Brazilian and other curiosities. This homo universalis immediately fell in love with the country that he thought 'one of the most beautiful in the world'. ${ }^{2}$ Artists and scientists accompanied him overseas to record the Brazilian reality through descriptions, paintings and scientific works. ${ }^{3}$ He ordered the construction of the 'ideal city' Mauritsstad, a sort of locus amoenus on the island of Antônio Vaz. Next to one of his palaces, Johan Maurits cultivated a garden in which he celebrated and domesticated the tropical wilderness. ${ }^{4}$

In extenso, the whole scientific and artistic project that developed under the impulse of Johan-Maurits can be seen as a way of taming Brazilian reality through the gathering of knowledge. The arsenal of images, maps and descriptions served to demonstrate that the Dutch fully understood the region and its inhabitants. During this period, and not only under the impulse of Johan-Maurits's humanist desire, a great amount of texts - in the broadest possible sense of that word were produced. These texts make clear in which way the colony was perceived by those in power. Obviously, their representations were not neutral, but highly biased accounts, revealing the colonisers' various interests. In the official discourse, authorised by the leaders of the West India Company, life in the colony was written down as well as given shape.

\footnotetext{
${ }^{2}$ Letter written the 3rd of February 1637 to the administrators. In: Boxer C.R., The Dutch in Brazil 1624-1654 (Oxford: 1957) 9.

${ }^{3}$ The Historia naturalis Brasiliae (1648) was published under his patronage, in collaboration with Georg Marckgraf, Willem and Johannes de Laet, and was considered the most comprehensive and detailed work on the natural history of Brazil until the early 19th century. The artists Frans Post and Albert Eckhout were also invited to paint the Brazilian people and landscapes. Caspar Barlaeus depicted the colony in Rerum per octennium in Brasilia et alibi nuper gestarum, sub praefectura Illustrissumi Comitis $\mathcal{F}$. Mauritii Nassoviae [...] (1647). The governor wanted to make this book more accessible and asked for a second publication in German in 1660. Most illustrations are by Frans Post (1612-1680).

${ }^{4}$ Silva M.A. da - Alcides M.M. "Collecting and Framing the Wilderness: The Garden of Johan Maurits (1604-79) in North-East Brazil”, Garden History, Dutch influences 30, 2 (2002) 153-176.
} 


\section{A Poet Adventurer ${ }^{5}$}

In what follows, I want to present a reading of three texts related to the Dutch poet-adventurer Elias Herckmans (1596-1644). Born in Amsterdam, Herckmans studied history and Latin before he began his professional career as a trader in Russia for the firm De Vogelaer. In the meantime he established a reputation as a writer with the Slach van Vlaenderen (1624), a homage to Maurits van Oranje, and as a poet with Sweedsche zeegtrompet (1631) and Lof der kael-koppen (1635), dedicated to Constantijn Huygens. His masterpiece is the Der Zeevaert Lof (1634), partly famous for one of the illustrations by Rembrandt van Rijn.

In 1635, Herckmans went into the service of the WIC and arrived in Recife on the 23rd of December. One year later he was appointed governor of the provinces of Paraíba, Itamaracá and Rio Grande. In 1641, he accompanied Admiral Lichthardt to Bahia, where the Dutch took revenge against the Portuguese for burning down Dutch sugar cane fields and sugar mills in Pernambuco. He undertook an inland expedition of two and a half months to Copaoba in search of silver mines. After returning to Holland for a brief stay in 1642, he accompanied Hendrik Brouwer as vice-general in the Dutch expedition to Chile. After Brouwer's death he took control of the expedition and conquered Valdivia in 1643. But the expedition failed and since Herckmans was in charge, he was blamed for the defeat. Soon after returning to Recife, he died on the 6th of January 1644. In that same year Johan Maurits left Pernambuco. In 1645, the tide turned and the economic and political situation of the Dutch in Brazil became more and more fragile. In 1654, Recife finally surrendered and after a peace treaty in 1661, the Dutch Republic recognized Portuguese sovereignty over Brazil.

As a member of Johan Maurits's scientific entourage, Herckmans's writings are embedded in the imagery created by the various Dutch artists in Brazil ${ }^{6}$ but his texts also give an account of the experience of a single human being. All colonists where different, according to

\footnotetext{
${ }^{5}$ The denomination was used by Alfred de Carvalho in his essay on Elias Herckmans. (Carvalho A. de, Aventuras e aventureiros no Brasil (Rio de Janeiro: 1930) 97-108.)

${ }^{6}$ See: Buvelot Q. (ed.), Albert Eckhout. A Dutch artist in Brazil (Zwolle: 2004), Schmidt B., Innocence Abroad. The Dutch Imagination and the Nere World, 1570-1670 Washington: 2001) and Brienen R.P., Visions of savage paradise. Albert Eckhout, court painter in colonial Dutch Brazil (Amsterdam: 2006).
} 
the period they lived in, their country of origin, or their social status. Herckmans's case therefore may not be exemplary for the Dutch attitude in the Brazilian colony - assuming there was a Dutch attitude. As a writer, was he gifted with a special gaze? And if so, is this reflected in his attitude and writings? What were his answers to the other reality displayed in the New World?

In what follows I hope to give an answer to these questions by reading the following texts: Herckmans's General Description of the Captaincy Paraíba and the accounts of two expeditions led by Herckmans to the interior of Brazil and to Chile, as they were transcribed by Barlaeus in his Rerum per octennium. ${ }^{7}$

\section{General Description of the Captaincy Paraíba}

In July 1639, Elias Herckmans wrote his fournaal. Algemene Beschrijuinghe van Paraiba. The Fournaal was written on behalf of the High Council, who wanted an inventory of the sugar mills in order to impose proper taxation. Herckmans gives a slow and very detailed description of the captaincy. The official report begins with an outline of the colonial history and a brief account of the administration. After this short introduction, Herckmans depicts all possible features of the captaincy: from nature (landscape, rivers, animals and plants) over buildings (villages, forts, churches, convents, sugar mills...) to the indigenous population. The fournaal ends with a long description of the Tapuia tribe.

The image drawn of the region is, predictably, that of an earthly paradise. This paradisiacal view originated with the first Europeans who set foot in the New World. Regarding Brazil, the Edenic image was already present in the letter sent by Pero Vaz de Caminha to the Portuguese king in 1500 and is still part of the Brazilian imagery

\footnotetext{
${ }^{7}$ Herckmans E., "Journaal. Algemene Beschrijvinghe van Paraíba (1639)", Bijdragen en Mededeelingen van het Historisch Genootschap (Utrecht: 1879) 318-367; Barlaeus C., Rerum per octennium in Brasilia et alibi gestarum, sub prefectura illustrissimi comitis I. Mauritii Nassovia $\mathcal{E}^{2}$ comitis, historia. Brasilia et alibi nuper gestarum, sub Praefectura Illustrissimi Comitis I. Mauritii, Nassoviae, Ec. Comitis, Nunc Vesaliae Gubernatoris E Equitatus Foederatorum Belgii Ordd. sub Auriaco Ductoris, Historia (Amsterdam, Blaeu: 1647) 213-23 (for the expedition to Copaoba), 277-90 (for the expedition to Chile).
} 
today. ${ }^{8}$ Herckmans inscribes his text in this tradition by emphasising the fertility of the land and the healthy air of the country. Paraíba is a little paradise, with fresh air, green and fertile soil producing the best sugar cane, clean rivers containing plenty of fish, and so on... It seems as though all growing plants and every living creature are mentioned in the long enumeration, engendering a very picturesque description of Paraíba.

Both in terms of style and themes, this text is very similar to those of other Dutch chroniclers of the same period. One of the recurring examples of this shared rhetoric is the importance given to the names of the perceived reality. Herckmans mentions words that define a typical Brazilian reality in their original language: in Portuguese (for example 'farinha', 'aldeia', 'capitania') or in the indigenous language, defined by Herckmans as the 'Brazilian' language. Words in Herckmans's vernacular language alternate with the indigenous ones, creating a hybrid speech, for instance in his depiction of the bay still known today as the Bahia da Traição, he mentions both the Portuguese name 'Bahia de Tracaon' - and the 'Brazilian' one - 'Tibira Caioutuba' or 'Caeiovael de Tibera'.'

Many names are etymologically explained. In fact, we owe the first account of the origin of the word Paraíba to Herckmans:

This region (or Captaincy) is named Paraíba; a Barbaric or, better, a Brazilian word meaning rough sea, arduous water, also a rough harbour to come in, [...] because Para is slithering harbour or river and $y b a$ is rough, whereof appears that this river, which is the biggest of the landscape, has its name from its slithering mouth, and in the same way the landscape has its name from the river, that is named, Paraíba. ${ }^{10}$

${ }^{8}$ Until today, the image of a tropical paradise persists in Brazilian popular culture. It is still used as a theme in songs and tv-shows, often ironically. About the construction of the myth: Buarque de Holanda S., Visão do Paraíso (Rio de Janeiro: 1959).

${ }^{9}$ Herckmans, "Journaal" 347.

10 'Dit landtschap (anders Capitania) wort genaemt Paraiba; is een Barbarische ofte, om beter te seggen, een Brasilaens woort ende betekent een verdorven see, een quaet water, item een quade haven om in te comen, [...] want Para is een haven ofte rivier met een bocht, en $y b a$ is quaet te seggen, waer uyt blijckt dat die reviere, die de grootste is van dit landtschap, haren naem heeft nae de mont ofte bochtige incomen derselver, ende wederom het landtschap sijnen naem nae de revier, dat is Paraiba, genaemt.' Herckmans, "Journaal" 319. 
Explaining the etymology leads to ethnology avant la lettre. It gives him a pretext to insert Indian tales in his exposition. One of the most enchanting examples is the following one:

The Potiguaras caught a young man from a hostile tribe and handed him over to a woman in the village to look after him, ordering her to guard him and to feed him well, for they wanted to eat him in the future. The woman acquitted herself so well of this task that she and the young man, whose name was Guará, fell in love with each other. For a long time the villagers couldn't get hold of Guará, because the elders of the village did not want to disturb the woman and letting her become a testimony for future violence. So they waited, until on a certain day she left the aldeia. The men took the opportunity and caught the young man taking him with them to slay him at a place near the river. The woman - it is uncertain if she came back earlier than foreseen or for other reasons - hearing what was happening, came running to the riverside, took the victim in her arms and, embracing him, screamed: "Ó Guara mama", meaning: my Guará, they want to kill you. That is how this river got its name. ${ }^{11}$

Through these descriptions we also learn more about the natives of Paraíba, the Pitiguares. Herckmans gives information about a typical Brazilian fruit, the cashew nut, and describes the effect caused by the drinking of a cashew concoction. The liquor makes the Brazilians so drunk that it makes them lazy and leads them to 'barbaric sins'. ${ }^{12}$ In explaining the origin of the word Tibery, he also informs us about sexual 'deviances':

The word Tibery comes from Tibero, which means Sodomic sins. Long time ago, in the neighbourhood of this water, the Pitiguares (fighting against the Tapuia, who are another kind of Indians who come from higher in the country) took a young Tapoeia-Indian as a prisoner and abused him there. Hence they named the place Tiberoy, which means water of the Buggery. ${ }^{13}$

${ }^{11}$ Nederveen Meerkerk H.C. van, "Indian tales. Relationship between the Indians and the Dutch in XVIIcentury Brazil", Indians do Nordeste: Temas e Problemas 2, UFAL (Maceió: 2000) 79.

12 '... waerin sij haer gansch droncken drincken, ende als dan vervallen tot grove ende barbarische sonden.' Herckmans, "Journaal" 347-48.

13 'Het woort Tibery is van Tibero affcomstich, dat betekent Sodomitische sonden. Omtrent dit water hebben de Pitiguares in ouden tijden (oorlogende tegens de Taboeyers, dat een ander soort van Brasilianen zijn, die hooger uyt het landt comen) eenen jongen Taboeyer gevangen genomen, dien sy aldaer misbruyckten, noemende de plaets Tiberoy, dat is te seggen het water der Boggery.' Herckmans, "Journaal" 331. 
It would be tempting to attribute this colourful writing to Herckmans's poetical background, but most Dutch chronicles apply similar strategies.

Even if Herckmans throws some light upon habits among the Pitiguares or 'Brazilians', he focuses more on another tribe, the Tapuia. Why did he choose to give a full description of the Tapuia tribe instead of focusing on the Pitiguares?

Tupi or not Tupi ${ }^{14}$ That was the question for the Dutch and the Portuguese colonizers in Brazil. In the beginning of the 17th century, the native population was divided by Europeans in two groups: the civilised or Tupi and the non-civilised or Tapuia. The Portuguese conquered and subjugated most of the Tupi-tribes. As a result, these tribes gave up their nomadic existence and started living along the coast in little villages. The Pitiguar whom Herckmans encountered in Paraíba were members of this group. Tapuia means 'from a different tongue' or 'enemy' in Tupi-language and the Portuguese used the same term referring to the natives they were unable to conquer. Tapuia were most often depicted naked to accentuate their savageness and 'noncivilized' status. Despite their savageness and their resistance to Christianization or European education, most of the tribes supported the Dutch in an alliance against the Portuguese. ${ }^{15}$

The priority for the Dutch was not to convert the Indians to their faith, but to establish relations of friendship and military alliance. They hoped this attitude would make it easier to achieve their goal of a flourishing colony based on trade and thus to make profit. The attitude of the Dutch towards the natives was more positive than their treatment of the African slaves. Indian slavery was prohibited since the creation of the WIC. The natives obtained freedom in order to guarantee the security of the Company. Violations against this rule were mostly severely punished.

\footnotetext{
${ }^{14}$ Andrade O. De, 'Manifesto Antropófago', Revista da Antropofagia I-1 (São Paulo: 1928). The Cannibal Manifesto is Brazilian modernism's most celebrated text.

${ }^{15}$ The Dutch attitude towards the natives of the New World was mainly positive. The image of America circulating in the Netherlands fitted into a local political context. Since around 1560, the Spanish attitude in the New World was compared to the own experience of tyranny. Similarities between the innocent Indian and the Dutch were portrayed in drawings, pamphlets and other texts. With the expiration of the Truce in 1621 the WIC decided to form alliances with the 'princes and natives of the lands' with whom they shared an antipathy towards 'savage Spaniards'. More on this topic see Schmidt, Innocence Abroad.
} 
For the Europeans who never left the 'civilized' part of the colony the wilderness with its inhabitants signified the unknown and the inaccessible. The Tapuia lived on the border of the colony. As allies they were part of the colonial community, but in their habits and customs they were incomprehensible, partly because they never gave up their nomadic existence, but most of all because their faith and rituals were very different from the Western way of thinking and acting. Everyone feared the Tapuia:

The country $[\ldots]$ is so beautiful and fertile, you couldn't wish for anything better, but we did not see anybody, everybody ran away, because they were afraid of our people, but most of all, as we could presume, of the Tapuia, whom they fear more than the Devil, because of their cruelty, knowing that they have no mercy, and not only towards people, they also kill and destroy Beasts...16

Leaving these 'savages' in the periphery was more advantageous to the Dutch. The Tapuia were held in an inhospitable and frightening place populated by dangerous animals and other fearful creatures like tigers, different kinds of ants and snakes. ${ }^{17}$

Herckmans ends his report with a negative image of Edenic Brazil. The Tapuia are not living in paradise; their arid territory looks like hell. The soil is not fertile but stony and barren; there is neither cattle running around nor colourful birds flying in fresh air. There are only wild pigs and poisonous snakes and the rivers are filled with maneating fish looking like pigs.

There is no caesura in style with the first part of the fournaal. The Tapuia, their territory and appearance are described with the same accuracy: they are tall and very strong; they have big heads with black hair; they run around completely naked..${ }^{18}$ Herckmans stresses their qualities: they are very humble towards their King and they obey unreservedly, especially when it comes to fighting the enemy. They lead a

16 ''t Landt [...] is soo schoon ende vruchtbaer, dat men't niet beter soude konnen wenschen, doch sagen daer niet een mensche, soo was alle 't volck verlopen, soo uyt vreese voor de onse, doch meest, als wel te vermoeden was van de Tapuyas, dewelcke sy, weghen hare wreetheyt, meer vreesen als den Duyvel, wetende datse niemandt quartier geven, ende niet de Menschen alleen, maar oock de Beesten dootslaen ende vernielen...' Laet J. de, Het Iaerlyck Verhael van Foannes de Laet 1624-1636. Boek XI-XIII (1634-1636) (The Hague: 1937) 48.

17 l'Honoré Naber S.P. (ed.), Toortse der zee-vaert door Dierick Ruiters (1623). Samuel Brun's Schiffarten (1624) (The Hague: 1913) 20-30.

18 Herckmans, "Journaal" 359. 
completely bestial and unconcerned life but they fight vigorously and are not afraid to kill. ${ }^{19} \mathrm{He}$ mentions that even if they sometimes visit the centre of the colony as friends, it is safer to escort them back to the border, otherwise they could hurt Dutchmen and cause other damage on their way. ${ }^{20}$ When it comes to their strength, he exaggerates their physical skills: little children already learn to walk at the age of 9 or 10 weeks and soon thereafter they run to the water and learn to swim; the oldest members of the tribe reach the age of 160 and some attain the age of $200 .{ }^{21}$ In fact, what he does, is enumerating the qualities of a good and strong ally. This is an official report for the High Council, to whom this kind of information is of great importance.

Johannes de Laet was the first Dutchman who described the Tapuia. Even though Herckmans probably relied on de Laet's descriptions, ${ }^{22}$ he adds new and valuable ethnologic elements. He gives for instance the reason for the Tapuia migration to the coast in the months of November, December and January. During this period no cashew is to be found, which is why they have to move closer ashore to find their food. ${ }^{23}$

Different aspects of the tribal life are mentioned: rites of passage, marriage (the ceremony, polygamic relationships), burial and cannibalistic practices. Most of the information is not new and can be found in other texts. Although Herckmans never witnessed them himself, his depiction of endocannibalistic practices is (again) very detailed. He notes how the Tapuia prepare their dead fellowmen very carefully in a dish during an anthropophagic ritual. Before the ceremony, they clean and braise the body. Every part of the body will be eaten, even the bones, which will be burnt and crushed to make flour. ${ }^{24}$

When it comes to their religion, Herckmans states that the Tapuia are 'ignorant' and 'uneducated'; they have 'no knowledge of the true God' but serve 'the Devil or some evil spirits'. ${ }^{25}$ He even stresses that

\footnotetext{
19 Ibid., 361.

${ }^{20}$ Ibid., 367.

${ }^{21}$ Ibid., 366.

${ }^{22}$ He relied most probably also on the accounts of previous authors like Staden and Thévet.

${ }^{23}$ Herckmans, "Journaal" 359.

${ }^{24}$ Ibid., 365.

25 Ibid., 360: 'Het syn onwetende ende ongeleerde menschen, geen kennisse hebbende vanden waren Godt ofte sijne geboden, maar integendeel dienen den Duyvel ofte eenigerhande boose geesten.'
} 
'they don't know what's baptism, nor circumcision'. ${ }^{26}$ Sorcerers living among them can predict the future and get in touch with the (evil) spirit, who can appear in different forms, as an animal or as a fellow Tapuia. Herckmans never witnessed such appearances himself, but he can rely on the testimony of several Dutch commanders who claim to have seen how the devil appeared among a Tapuia clan. ${ }^{27}$

Herckmans mentions the devil, the appearance of spirits and endocannibalism with neither horror nor astonishment. The satanic and cannibalistic motives often recur in the corpus of Dutch texts about Brazil. Stereotypical features of barbarism like nakedness and cruelty are ascribed to the Tapuia, who are perceived as being part of untamed nature. The Brazilian reality in general is represented through the dialectic of the Edenic and the diabolic. The coast and the Tupi Indian (Eden) are the opposite token of the interior and the Tapuia Indian (Hell). Even though the Fournaal offers new ethnological information, it does not give an accurate representation of the reality of the Tapuia but partakes of a European worldview. By doing so, it proves the difficulties in obtaining knowledge about the Indian reality.

More than a century after the first discoveries the reality of the New World and its inhabitants are no longer an unwritten page, in fact they never were. The first texts encouraged what some call the 'invention of Latin America'. Before Columbus set foot in the New World, Europe had a long tradition of writings about other cultures. The first representations were based on existing stories and tell us more about the European beliefs and value systems of that epoch than about the newly discovered regions. These texts were created within a 'writing that conquers' where the savage functioned as a 'blank page' that was filled with Old World representations and meanings. ${ }^{28}$

Observation occurs through the mediation of familiar cultural schemes and Herckmans's gaze is no exception. He does not render a total reliable description of Indian tribes and still uses stereotypical images: the barbarian, the cannibal, the sorcerer.... In this way, he annihilates the cultural diversity. The Indian is incorporated in the

\footnotetext{
26 Ibid., 364: 'weten sij oock noch van doop, noch van besnijdenis'.

27 Ibid., 360.

28 The phrase is that of Michel de Certeau, who described the encounter as a conquest and confrontation, during which the scriptural and the oral aspect interact. The voyagers possessed a powerful weapon: 'l'écriture conquérante'. The New World was a blank page, the European exerted their 'vouloir écrire' upon the natives who functioned as 'un corps à écrire'. Certeau M. de, L'écriture de l'histoire (Paris: 1975).
} 
Western imagery and gets a classification and value during this process; the Indian becomes a stereotypical image. The symbolic value of the different Indian practices is negated; this value does not exist in the Western world and therefore cannot be defined in terms of the self. The cultural difference of the Indian is unreachable, which makes the acquisition of knowledge about the other impossible. ${ }^{29}$

However, even if Herckmans's Journaal was written on behalf of the High Council and reflects therefore the Company's interest and even if Herckmans's representation relies on common stereotypes, he also adds new little details and in these details we find very valuable information about the Indian customs and habits. When a couple of months later Herckmans ventures across the continent at the borders of the colony he meets on different occasions with natives. Does he manage to cross the cultural boundary and to look behind the veil of stereotypical images?

\section{Seeking and Framing the Wilderness}

Herckmans undertook two very different expeditions outside the colony. During the first one (into the interior) he wanted to find silver mines. The second expedition (to Chile) was a military campaign to conquer new territories, make alliances with the local Indian population and find gold. Why did he want to explore new regions? Was he led by curiosity, did he want to discover unknown territories or get in touch with natives? Was he in pursuit of personal profit and fame? He cannot tell us anymore, nor will we find an answer in his writings as the original reports got lost. To build our opinion we can only rely on the official chronicles. In Barlaeus's view he was led by patriotic feelings.

\footnotetext{
${ }^{29}$ Using stereotypes not only blocks the access to knowledge about the other but at the same time, through reiteration, disavows cultural differences. Homi K. Bhabha reads stereotypes in colonial discourse in terms of fetishism. The stereotype assumes a totalized fixity of the image of the other. 'The stereotype is not a simplification because it is a false representation of a given reality. It is a simplification because it is an arrested, fixated form of representation [...].' Bhabha H.K., 'The other question: Stereotype, discrimination and the discourse of colonialism', The location of culture (London: 1994) 74-75.
} 
While others achieved to install Dutch power with weapons and war he endeavoured to increase Dutch power and wealth through exploration of the lands and the study of people. Fate, however, superior to human intention, didn't allow the realization of this great performance. ${ }^{30}$

On the 3rd of September 1641, Herckmans leaves Recife to undertake an inland expedition. His ambition is to find the silver mines reported to lie in Copaoba. Initially, 53 soldiers accompany him, together with 60 Indians, some 'Brazilian' women and 3 or 4 volunteers 'attracted by travel and new lands'. ${ }^{31}$ In the first days, 13 soldiers and 24 Indians already leave the expedition because of illness. The survivors persevere, cross rivers, walk through sugar cane fields, climb mountains and cut their way through the jungle with sickles. During the first weeks of the journey they are still inside the colony. They venture through known territory, across the homeland of the accompanying Potiguar. ${ }^{32}$

Once they reach the border of the colony the journey gets tougher. On unknown territory even the Potiguar do not feel at ease anymore. Filled with apprehension they are unwilling to enter a region where nobody ever went. They are frightened, refuse to go on and advise to return.

They arrived at a point were nature denies any further passages, through dense woods, abysses of hills, the meandering paths, with neither hope for glory nor profit. ${ }^{33}$

The soldiers lose their courage and start to panic. Nonetheless, Herckmans manages to persuade his men to go on. In an imposing oration he praises their strength and courage and explains how the expedition only began and that they should not listen to their fear. He guarantees his troops that food will easily be found by hunting and that they will encounter water in the valleys. After sending ten men back to Recife he convinces the others to strive further for glory and profit.

30 'Potentiae Belgarum alii viam aperuere armis et bello. hic, studiosa terrrarum et populorum indagatione, industria potentiam opesque augerere studuit. Licet egregiis coeptis abnuerit fortuna, humanis consiliis potentior.' Barlaeus, Rerum per octennium, 313 .

${ }^{31}$ Ibid., 215: 'solo peregrinationis studio et terrarum novitate capti.'

32 The Potiguar used to live in the region before they were forced by the Portuguese to resettle by the coast.

${ }_{33}$ Barlaeus, Rerum per octennium 219: 'duci se, quo viam natura negaret, per opaca silvarum, montium praerupta, viarum anfractus, nulla gloriae, nulla emolumenti exspectatione.' 
With renewed energy they resume the adventure in the direction of Copaboa. However, after an exhausting climb over a steep mountain they realize their final goal is still many miles away. The more they ascend, the more the men get physically tired. In addition, they are afraid their food supplies will not last for many more days. Afflicted with thirst and hunger, the soldiers refuse to take another step. Herckmans is eventually forced to turn back. After a two and a half months' journey, they are back in Recife, empty-handed.

The account, i.e. Barlaeus's representation of the expedition, is characterized by the same hybrid speech as Herckmans's fournaal. This rhetorical feature is typical for the corpus of texts about Dutch Brazil. It is difficult to determine which words and etymological clarifications Barlaeus took from Herckmans and which ones he added himself. Barlaeus retranscribes many flora and fauna encountered during the journey to Copaoba and comments on 'Brazilian' and Portuguese names. Some interest ing examples:

- The hill from where the group started their return home received the name Monte do Retorno (Hill of return). ${ }^{34}$

- The torrent Capiiraguaba means 'the torrent where the horses drink' ${ }^{35}$

- The 'River of Musk' got his name from its strong smell of crocodiles and snakes, very similar to the odour of musk. ${ }^{36}$

- The mountain top Irupari-bakai means, 'here the devil looked back'. The name goes back to an Indian legend: when the devil climbed these mountains he was so overwhelmed by the height that when arriving at the top, he looked back. ${ }^{37}$

After a brief stay in the Netherlands in 1642, Herckmans is sent out to Chile. Admiral Hendrik Brouwer, a former Governor-general for the VOC, asks the WIC permission to organise an expedition to the Southern part of the American continent. The WIC consents and sends a fleet with the instruction to conquer the city of Valdivia, to capture Peru, to occupy the Spanish gold and silver mines and to 'liberate'

\footnotetext{
${ }^{34}$ Ibid., 221: 'Mons unde digressi, reditus Mons dictus.'

35 Ibid., 218: 'torrens equationis equorum'.

${ }^{36}$ Ibid., 218.

${ }^{37}$ Ibid., 217: 'Irupari-bakau. Hic Respexit Diabolus.'
} 
the natives from the 'Spanish tyranny'. Five ships leave the Brazilian coast in January 1643 but only four manage to cross Cape Horn and to reach the island Chiloé safely. Soon thereafter, they invade the city of Valdivia but Brouwer dies on the 7th of August. From then on Herckmans, vice-general of the expedition, takes control.

Initially, the situation looks promising. They manage to convince some local tribes to join forces in a partnership against the Spanish. On the 29th of August, Herckmans shows his diplomatic qualities in a grand oration for about 300 people. He wants to prove to the natives that the Dutch feel nothing but sympathy towards them. In his speech he stresses the heroism of the Chileans against the Spaniards and also tells about the Dutch earlier exploits in the Orient and in Brazil. Underlining their military power, he wants to make clear how powerful they could be against the Spaniards if they joined forces. As a proof of friendship he presents them with ceremonial gifts and with the 'letters of credential' from the States General to the Chileans. ${ }^{38}$ Unfortunately, no copy survives.

Five days later Herckmans gives a second grand and dramatic speech and proposes an alliance based on friendship and trade. $\mathrm{He}$ makes a diplomatic mistake though by asking for the Chileans' help to conquer the gold mines. This reminds the Chileans of the Spanish and the tyranny they had inflicted in their pursuit of gold. Thereafter the alliance with the natives abruptly comes to an end. On the 14th of September, in a letter to Constantijn Huygens, he puts it as follows:

They affirm that they do not posses any provision of gold, but they pointed out where the mines are. However, they do not want to work there, or being forced to; the gold being the only cause of the war between them and the Castilians. ${ }^{39}$

As the Dutch are largely outnumbered in men and equipment by the Spanish, Herckmans asks the WIC several times for support, but no reinforcement is sent. Finally, to make the situation even more unstable, there is a food shortage and the soldiers start to mutineer. The Chilean

${ }^{38}$ Schmidt, "Exotic Allies" 453.

39 'Goud, seyden sy, in voorraat niet te hebben, maer wesen de mijnen aen daer ' $t$ is, doch wilden niet aen 't mineren, noch oock daertoe gedwongen wesen; het goud de enigste oorsaeck van den oorlog tusschen haer en de Castellanen tewesen'. Worp J.A. (ed.), De briefwisseling van Constantïn Huygens (1608-1687), (The Hague: 1911-1917), vol. III, 444-445. 
adventure ends in failure. Herckmans is constrained to leave Chile and the newly conquered city. In an official letter to Johan-Maurits he briefly explains the reasons for the defeat. Back in Brazil, the company blames Herckmans for the unsuccessful enterprise. There is no time to put him to trial, however, as he dies soon after his return to Recife.

Nevertheless, Herckmans did not return empty-handed from Chile; he brought back an invaluable treasure: a vocabulary of the Chilean Indians, probably Arouak. Barlaeus inserted the whole document in his Rerum per octennium. The glossary contains over 400 words and more than 40 expressions, which give ethnological information about the habits of the Indian population.

Barlaeus added general information about the natives of Chile and portrays them with the stereotypical features of savages. In his description Barlaeus notes that they have scarcely any marks of religion and he enumerates their 'bad' qualities: they are lazy, undisciplined and often get drunk. They have one quality, the essential one for an ally: they fight almost as well as Europeans. ${ }^{40}$ Their general traits resemble those of the Tapuia as described by Herckmans in the Fournaal.

The two accounts seem to render a binary vision of the Brazilian reality and to present the civilized/savage model of colonial identification. They include some of the common 17th Century European stereotypes about the nature and people of Brazil. Since 1492, writers and artists had written, mapped and illustrated the New World. Stories and other representations influenced each other, creating a vast intertextual network around an imaginary space. The appropriation of knowledge about exotic regions and cultures involved the use of stereotypes and inevitably led to commonplaces and prejudices. ${ }^{41}$

Concerning the adventure to Copaoba, Barlaeus sets the atmosphere of the experience. The deeper the expedition penetrates the interior, the more difficult the journey becomes and the more the company and the Potiguar get scared. Once they enter the unknown territory, they enter the homeland of the Tapuia, the wilderness, a space only inhabited by beasts and vermin:

\footnotetext{
${ }^{40}$ Barlaeus, Rerum per octennium 277-278.

${ }^{41}$ Burke P., A Social History of Knowledge. From Gutenberg to Diderot (Cambridge: 2000) 196.
} 
Everywhere they found plenty of mice, rats and snakes: but no goats nor any kind of pig. They only caught three or four armadillos. During those days no birds were to be seen in the air. ${ }^{42}$

The inland of Brazil functions as the counter image of the colony. The wilderness is something out there, something alien. At first glance, the image given by Barlaeus appears to be reducible to the dichotomy coast/interior. Between what is known or comprehensible - the colony - and what is not - the wilderness - runs a clear frontier. The unknown territory simultaneously generates curiosity and threat, resulting in an ambivalent desire to seek and frame the wilderness. To cross the border is to penetrate the obscure, a frightening space where barbarism and savageness reign. ${ }^{43}$ During the centuries of colonization this border was gradually displaced, as more territories and Indians were incorporated in the space of the self. The complete domestication of the wilderness never took place, however. Up to this very day, parts of the Brazilian interior are still unknown. Recently, in June 2008, Brazil discovered a still uncontacted Indian tribe in the Amazon region. ${ }^{44}$

A closer reading of the accounts uncovers a more complex reality and reveals a tension between Herckmans's experience and the descriptions of that experience by Barlaeus. We have to keep in mind that the Rerum per octennium is not written by an eyewitness - Barlaeus never set foot in the New World. The famous Latinist based his account of the Dutch colonial empire on the abundant sources available in Holland at the time and rewrote Herckmans's report following humanist conventions of the Golden Age. ${ }^{45}$ Nevertheless, the colonial binary discourse is destabilised by the little traces left by Herckmans

\footnotetext{
${ }^{42}$ Barlaeus, Rerum per octennium 222. 'murium, gliriumque et anguium toto itinere abundè fuit. caprearum, aut suilli generis nihil. Armadilliae non nisi tres quatorve captae. Aër quoque per hos dies, absque volucirbu, visus.'

${ }^{43}$ Pompa C., Religião como Tradução. Missionários, Tupi e Tapuia no Brasil colonial, EDUSG (Bauru: 2003) 199-227.

${ }^{44}$ FUNAI, the Brazilian government's Indian affairs department, estimates there are still approximately 68 uncontacted tribes in Brazil, about two dozen tribes have been officially confirmed. URL: www.funai.gov.br

${ }^{45}$ Barlaeus did not want to render a critical view of the colony. On the contrary, the Rerum per octennium celebrates unconditionally Johan Maurits's achievements in Brazil. It is a monumental work filled with allusions to ancient texts. The comparison with historical figures serves to demonstrate that the Dutch exploits in the Brazilian colony were even more remarkable. See Schmidt, Innocence abroad 254-57 and Grafton A., New Worlds, Ancient texts. The Power of Tradition and the Chock of Discovery (Harvard: 1995).
} 
in Barlaeus's text. The Indian words were studied and left by Herckmans. Through these words we get fragments of life of the 'other', not only of the Indian who spoke them but also of Herckmans who was the first to write them down. We owe the glossary to his interest in the Indian language and by extension in the Indian culture.

One can argue that the study of the practices and the language of another culture are in support of the conquest. Knowledge about the newly discovered territories and people was used not only to conquer more effectively, but also as a tool in the competition with other European companies. As was the case with maps ${ }^{46}$ possessing cultural information about native people was far from politically neutral and could have serious implications. ${ }^{47}$ But even if it was Herckmans's goal to give the Company a functional tool for the conquest of Chile, as a patriotic act or to obtain personal fame; and even if as a poet and member of Johan Maurits's entourage, Herckmans was probably driven by a humanist interest in the exotic - the words and idioms were collected and put into the frame of the glossary, the same way Johan Maurits organised his tropical garden in Recife -, it still required his curiosity to lead this kind of research. In the meantime, an encounter took place between Herckmans and the 'other'. Fragments of that encounter emerge from the texts as subversive forces and break through the stereotypes giving us what Barthes called 'un effet de réel'.

\section{Gazing at the Border}

It was not my aim, as it was for Lévi-Strauss, to obtain objective information about the Brazilian Indian or about a Dutch poet. Instead, I gave my representation of a past reality through a description of three texts. This description is not and cannot be complete, for I am convinced that describing is not only 'être inexact ou incomplet, c'est changer de structure, c'est signifier autre chose que ce qui est montré'. 48

\footnotetext{
${ }^{46}$ Second treasure Herckmans brought back to Recife, a shorter route near Strait Magallan in the South of Argentina to the Pacific Ocean, called Strait Brouwer.

${ }^{47}$ Burke, Social History of Knowledge 74-77.

${ }^{48}$ Barthes R., "Le message photographique", L'obvie et l'obtus (Paris: 1982) 12.
} 
Through my reading I started a dialogue with a 17th Century Dutch mercator sapiens. Herckmans can't be reduced to a mere 'poetadventurer' who was seeking personal fame and profit in the New World. Lingering at the border of the colonial society, he tried, consciously or not, to look behind the veil of stereotypes. The frontiers of the colonial world were real and imaginary at the same time. At this border a double encounter took place: his encounter with the natives and my encounter with him. 


\section{Selective Bibliography}

Barlaeus C., Rerum per octennium in Brasilia et alibi gestarum, sub prefectura illustrissimi comitis I. Mauritii Nassovice $\mathcal{E}^{2}$ comitis, historia. Brasilia et alibi nuper gestarum, sub Praefectura Illustrissimi Comitis I. Mauritï, Nassoviae, Ėc. Comitis, Nunc Vesaliae Gubernatoris E' Equitatus Foederatorum Belgii Ordd. sub Auriaco Ductoris, Historia, (Amsterdam, Blaeu: 1647) 213-223, and 277-290.

Barlaeus G., História dos feitos recentemente praticados durante oito anos no Brasil (1647) (Recife: 1980).

Barthes R. 1968, "L’effet de réel", Oeuvres Complètes II. 1966-1973 (Paris: 1994), 479-484.

Belsey C., "Reading Cultural History", in Spargo T. (ed.), Reading the past (Houndmills: 2000).

Bнавна H.K., "The other question: Stereotype, discrimination and the discourse of colonialism", The location of culture (London: 1994).

Boxer G.R., The Dutch in Brazil 1624-1654 (Oxford: 1957).

Burke P., A Social History of Knowledge. From Gutenberg to Diderot (Cambridge: 2000).

BRIENEN R.P., Visions of savage paradise. Albert Eckhout, court painter in colonial Dutch Brazil (Amsterdam: 2006).

Buvelot Q. (ed.), Albert Eckhout. A Dutch artist in Brazil (Zwolle: 2004).

Carvalho A. de, Aventuras e aventureiros no Brasil (Rio de Janeiro: 1930).

Certeau M. de, L'écriture de l'histoire (Paris: 1975).

Grafton A., New World, Ancient, Texts. The Power of Tradition and the Chock of Discovery (Harvard: 1995).

Greenblatt S., Marvellous Possessions. The wonder of the new world (Oxford: 1994).

Herckmans E., "Journaal. Algemene Beschrijvinghe van Paraíba (1639)", Bijdragen en Mededeelingen van het Historisch Genootschap (Utrecht: 1879) 318-367.

L'Honoré Naber S.P. (ed.), Toortse der zee-vaert door Dierick Ruiters (1623). Samuel Brun's Schiffarten (1624) (The Hague: 1913).

Mello G. de, 1947, Nederlanders in Brazilie (1624-1654). De invloed van de Hollandse bezetting op het leven en de cultuur in Noord-Brazilï (Zutphen: 2001).

Montanus A., De Nieuwe en onbekende weereld: of Beschryving van America en 't zuid-land, vervaetende d'oorsprong der Americaenen en zuid-landers, gedenkwaerdige togten derwaerds, gelegendheid der vaste kusten, eilanden, steden, sterkten, dorpen, tempels, bergen, fonteinen, stroomen, huisen, de natuur van beesten, boomen, planten en vreemde gewasschen, Gods-dienst en zeden, wonderlijke voorvallen, vereeuwde en nieuwe oorloogen: verciert met af-beeldsels na 't leven in America gemaekt (Amsterdam, J. Meurs: 1671).

Nederveen Meerkerk H.C. van, "Indian tales. Relationship between the Indians and the Dutch in XVII century Brazil", Indians do Nordeste: Temas e Problemas 2, UFAL (Maceió: 2000) 30-79.

Nieuhof J., Gedenkweerdige Brasiliaense Zee-en Lant-Reize (Amsterdam, Weduwe Jacob van Meurs: 1681).

Pompa C., Religião como Tradução. Missionários, Tupi e Tapuia no Brasil colonial, EDUSC (Bauru: 2003).

Seed P., Ceremonies of Possession. Europe's Conquest of the New World 1492-1640 (Cambridge: 1995).

Schmid $\mathrm{B}$., Innocence Abroad. The Dutch Imagination and the New World, 1570-1670 Washington: 2001).

Thévet A., Les singularités de la France Antarctique. Le Brésil des cannibales au XVI siècle (Paris: 1983).

Todorov T., La conquête de l'Amérique. La question de l'autre (Paris: 1982).

Worp J.A., "Elias Herckmans", Oud-Holland 11/3 (1893) 162-173.

Worp J.A. (ed.), De briefwisseling van Constantijn Huygens (1608-1687), vol. III (The Hague: 1911-1917). 
